\title{
Development of Oxygen Concentration Gradients in Flesh Tissues of Bulky Plant Organs
}

\author{
Nihal C. Rajapakse', Nigel H. Banks, Errol W. Hewett, and Donald J. Cleland ${ }^{2}$ \\ Department of Horticultural Science, Massey University, Palmerston North, New Zealand
}

Additional index words. Malus domestica, Prunus persica, Pyrus serotinu, modified/controlled atmosphere storage, flesh resistance

\begin{abstract}
Steady-state oxygen diffusion in flesh of apples (Malus domestics Borkh. Cvs. Braeburn and Cox's Orange Pippin), Asian pears (Pyrus serotina Rehder. cvs. Hosui and Kosui), and nectarines [Prunus persica (L.) Batsch. CVs. Red Gold and Sunglo] was studied using a nondestructive method at 20C. Fruit flesh was found to exert a significant resistance to $\mathrm{O}_{2}$ diffusion resulting in measurable $\mathrm{O}_{2}$ gradients between tissues immediately beneath the skin and those at the fruit center for all these fruits. The magnitude of these $O_{2}$ gradients varied between crops and cultivars and depended on the respiration rate and on effective $O_{2}$ diffusivity in fruit flesh $\left(D_{e}\right)$. Values of $D_{c} v a r i e d$ with the cultivar and were broadly consistent with intercellular space volume. The range of $D_{e}$ values obtained suggested that $\mathbf{0}_{2}$ diffusion in fruit flesh takes place in a combination of series and parallel modes in the intercellular space and fluid/solid matrix of the flesh. The results imply that $\mathrm{O}_{2}$ diffusivity in flesh tissues must be taken into consideration in the determination of critical external $\mathrm{O}_{2}$ level in controlled/modified atmosphere (CA/MA) storage.
\end{abstract}

Respiration and skin resistance to gas diffusion result in gas concentration gradients between the external atmosphere and the atmosphere just beneath the fruit skin (Burg and Burg, 1965). In addition, there are gas concentration gradients between tissues at the fruit center and those just beneath the fruit skin, and it is these gradients that dictate the direction of gas diffusion within the fruit. The magnitude of these gradients is influenced by $D_{e}$, fruit size, and rate of gas production or consumption.

Most experimental evidence indicates that the $0_{2}$ concentration gradients across flesh tissues of apple are small, due to the relatively large intercellular space volume, and therefore have no physiological significance (Burton, 1982; Burg and Burg, 1965; Trout et al., 1942). However, Nobel (1983) reported that the apparent diffusivity of gases in apple flesh is only 10- to 20 -fold higher than that of the fruit skin and suggested that considerable concentration gradients may develop across the flesh of large fruit. Solomos (1987) also reported the existence of significant $\mathrm{CO}_{2}$ gradients between center and surface of peeled apples. Preliminary work with 'Golden Delicious' apples has also shown that significant $\mathrm{O}_{2}$ gradients can exist between surface tissues and the central cavity (Rajapakse et al., 1989).

The flesh of dense organs, such as potatoes and avocados, might be expected to exert a considerable resistance to gas movement due to limited intercellular space volume. Ben-Yehoshua et al. (1963) and Burg and Burg (1965) demonstrated that flesh tissues of immature and climacteric avocado fruit exert a significant resistance to $\mathrm{CO}_{2}$ movement, creating a large concentration gradient across the flesh tissues. Recent studies by Banks and Kays (1988) have also indicated the existence of significant flesh resistance to gas diffusion in potatoes.

These results indicate that flesh resistance to $\mathrm{O}_{2}$ diffusion in horticultural commodities may not be negligible and should therefore be considered in attempts to understand modified atmosphere effects and in the determination of critical external $\mathrm{O}_{2}$ levels that can be used safely in modified or controlled atmospheres. Therefore, the present study was conducted to es-

Received for publication 16 Oct. 1989. The cost of publishing this paper was defrayed in part by the payment of page charges. Under postal regulations, this paper therefore must be hereby markedadvertisement solely to indicate this fact.

'Present address: Dept. of Horticulture, Clemson Univ., Clemson, SC 29634. ${ }^{2}$ Dept. of Biotechnology, Massey Univ., Palmerston North, New Zealand. timate internal $\mathrm{O}_{2}$ concentration gradients in flesh tissues of apples, Asian pears, and nectarines and to use these data to obtain preliminary estimates for $\mathrm{D}_{\mathrm{e}}$ of these fruits. Knowledge of $\mathrm{O}_{2}$ diffusivity will be particularly important in the development of models used to study gas exchange behavior of produce in controlled or modified atmospheres.

\section{Materials and Methods}

Plant material. Freshly harvested (at commercial maturity) 'Cox's Orange Pippin' and 'Braeburn' apples were obtained from the New Zealand Apple and Pear Marketing Board, Hastings, New Zealand. 'Red Gold' and 'Sunglo' nectarines and 'Hosui' and 'Kosui' Asian pears were obtained from a local fruit distributor. All fruits were stored at 1 to $2 \mathrm{C}$ for 2 to 3 days until the beginning of the experiment. Even-sized, blemish-free fruit were selected, washed in running water, wiped dry, and allowed to equilibrate overnight to $20 \mathrm{C}$ before experimentation. Calyx and stem end cavities were covered with petroleum jelly to prevent possible air movement through the openings in these ends.

Determination of equilibration time of chambers (Expt. 1). Two 2-ml glass vials, from which the bottoms had been removed and tops fitted with a 0.4-ml plastic tube, were attached over two to three lenticels on opposite sides of each of 10 fruit from each cultivar using polyvinyl acetate adhesive (Fig. 1). After allowing adhesive to dry for $24 \mathrm{hr}$, the chambers were sealed by inserting a rubber septum into the plastic tube fitted onto the chamber. The well formed in the plastic tube after sealing the chamber was filled with water to prevent gas leaks through the rubber septum and atmospheric contamination of samples being withdrawn for $\mathrm{O}_{2}$ estimation. A 50- $\mu$ l gas sample was taken from each chamber at $0,4,8,24,28,32,48$, and $72 \mathrm{hr}$ after sealing, and the $\mathrm{O}_{2}$ concentration in the sample was measured by using an $\mathrm{O}_{2}$ sensor (Banks, 1986).

Estimation of $\mathrm{O}_{2}$ concentration gradient between surface and center of fruit (Expt. 2). Equilibrated $\mathrm{O}_{2}$ concentrations were measured on 50- $\mu$ l samples taken from two 2-ml chambers attached onto opposite sides of each of 15 fruits in each cultivar.

Abbreviations: CA/MA, controlled atmosphere/modified atmosphere; $\mathrm{D}_{\mathrm{e}}$, effective diffusivity of $\mathrm{O}$ in fruit flash; $\left[\mathrm{O}_{2}\right]_{c}, \mathrm{O}_{2}$, concentration at fruit center; $\left[\mathrm{O}_{2}\right]$, external $\mathrm{O}_{2}$, concentration (assumed to be $0.2095 \mathrm{~atm}$ ); $\left[\mathrm{O}_{2}\right]_{\mathrm{s}}, \mathrm{O}_{2}$ concentration in tissue just beneath fruit skin; R, skin resistance to $\mathrm{O}_{2}$ diffusion. 


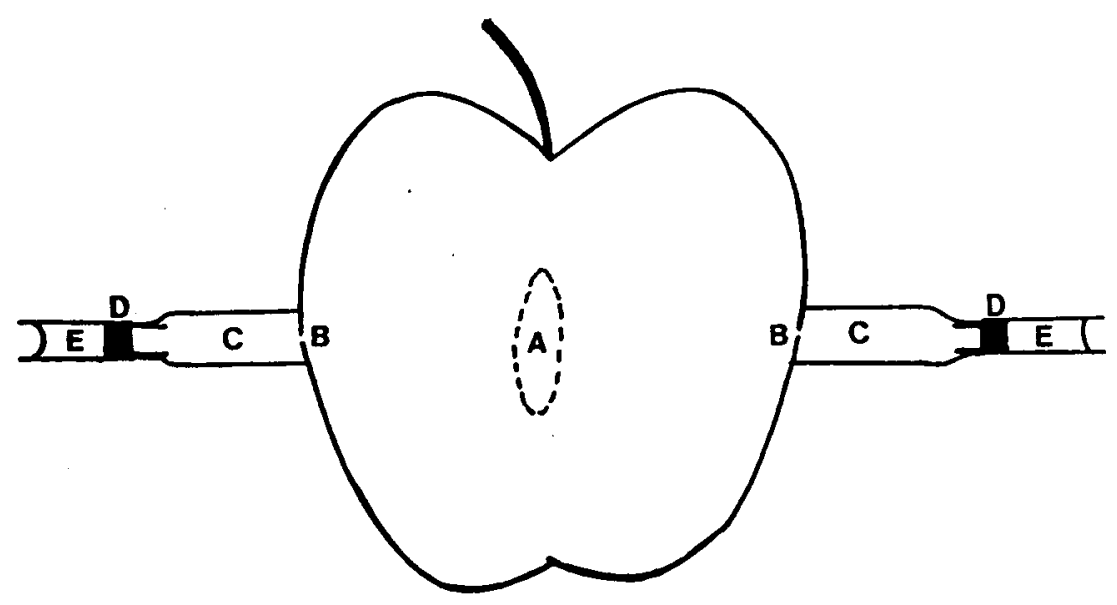

Fig. 1. Arrangement of sampling chambers on the fruit surface. (A) Fruit core cavity; (B) lenticel; (C) glass chamber; (D) rubber septum; (E) plastic tube with water.

$\left[\mathrm{O}_{2}\right]_{\mathrm{s}}$ was estimated as the average of values obtained for the two chambers on each fruit.

$\left[\mathrm{O}_{2}\right]_{\mathrm{c}}$ was determined by direct sampling of $0.5 \mathrm{ml}$ of gas from the central core cavity of apples and Asian pears and $\approx 0.2$ $\mathrm{ml}$ of gas taken from the center (near the seed) of nectarines by use of a l-ml plastic syringe fitted with a 4-cm-long needle on the same fruit after $\left[\mathrm{O}_{2}\right]_{\mathrm{s}}$ measurements were completed. Dead air space in the syringe and air trapped between the septum and syringe wall were replaced by saturated $\mathrm{NaCl}$ solution or water to prevent contamination 'of the internal gas sample. A copper fuse wire was passed" through the needle bore to prevent blockage while the needle was inserted into the fruit. All internal gas samples were taken from fruit immersed in water. Oxygen concentration was quantified from $50-\mu \mathrm{l}$ samples as described before.

Respiration rate of the same experimental fruit was estimated from measurements of the change in 0 concentration in 600$\mathrm{ml}$ glass jars fitted with septa in which fruit were sealed for 1 $\mathrm{hr}$ at 20C. Oxygen concentrations in l-ml samples were quantified by gas chromatography. In addition, respiration rate was followed over time on a separate sample of representative fruit of each cultivar to follow the changes in gas exchange and fruit ripening.

Following respiration measurements, flesh firmness was determined on opposite pared fruit surfaces using a hand-held penetrometer (McCormick FT 011, Yakima, Wash.) fitted with an 8-mm plunger. Gas-filled intercellular space volume of individual fruit $(\epsilon$, percent) was determined from $\approx 25$-g samples taken through the flesh (including skin and flesh down to the central core cavity in apples and Asian pears and skin and flesh down to the seed cavity in nectarines) by vacuum infiltration with water as described by Kushman and Pope (1968).

Skin resistance to $\mathrm{O}_{2}$ diffusion was calculated from the following equation assuming that respiration rate was uniform throughout the fruit and that fruit were spherical (Burg and Burg, 1965):

$$
\mathrm{R}=\mathrm{A} \cdot\left(\left[\mathrm{O}_{2}\right]_{\mathrm{e}}-\left[\mathrm{O}_{2}\right]_{\mathrm{s}}\right) / \mathrm{J}
$$

where $\mathrm{R}=$ skin resistance to $\mathrm{O}_{2}$ diffusion $\left(\mathrm{s} \cdot \mathrm{cm}^{-1}\right), \mathrm{J}=$ total flux of $\mathrm{O}_{2}\left(\mathrm{ml} \cdot \mathrm{s}^{-1}\right)$, and $\mathrm{A}=$ surface area $\left(\mathrm{cm}^{2}\right)$.

Effective diffusivity of $\mathrm{O}_{2}$ in flesh tissues was estimated from the analytical solution for gas diffusion at equilibrium, assuming that both respiration rate and intercellular space volume were uniform throughout the flesh and that fruit were spherical (Car- slaw and Jaeger, 1959).

$$
\mathrm{D}_{\mathrm{e}}=\mathrm{ad}^{2} / 24 \cdot\left(\left[\mathrm{O}_{2}\right]_{\mathrm{s}}-\left[\mathrm{O}_{2}\right]_{\mathrm{c}}\right),
$$

where $\mathrm{D}_{\mathrm{e}}=$ effective diffusivity of $\mathrm{O}_{2}$ in fruit flesh $\left(\mathrm{cm}^{2} \cdot \mathrm{s}^{-1}\right)$, $\mathrm{a}=$ respiration rate $\left(\mathrm{ml} \mathrm{O}_{2} / \mathrm{cm}^{3}\right.$ tissue per second), and $\mathrm{d}=$ fruit diameter $(\mathrm{cm})$.

Experimental design and analysis. Fifteen single-fruit replicates from each cultivar were used in the experiment. The data were analyzed using analysis of variance (SAS Institute, Cary, N.C.). Least-square means were computed and mean comparison was carried out by Duncan's multiple range test or by single degree of freedom contrasts at $P=0.05$. Each experiment was repeated once and, since no difference was found between experiments, data were pooled for further analysis.

\section{Results and Discussion}

In Expt. 1, $\mathrm{O}_{2}$ concentration in chambers attached to the skin decreased rapidly after the chambers were sealed and reached an equilibrium level after $48 \mathrm{hr}$ in apples and Asian pears (Fig. 2). For nectarines, chamber $\mathrm{O}_{2}$ concentration reached the equilibrium level $8 \mathrm{hr}$ after sealing chambers. Changes in chamber

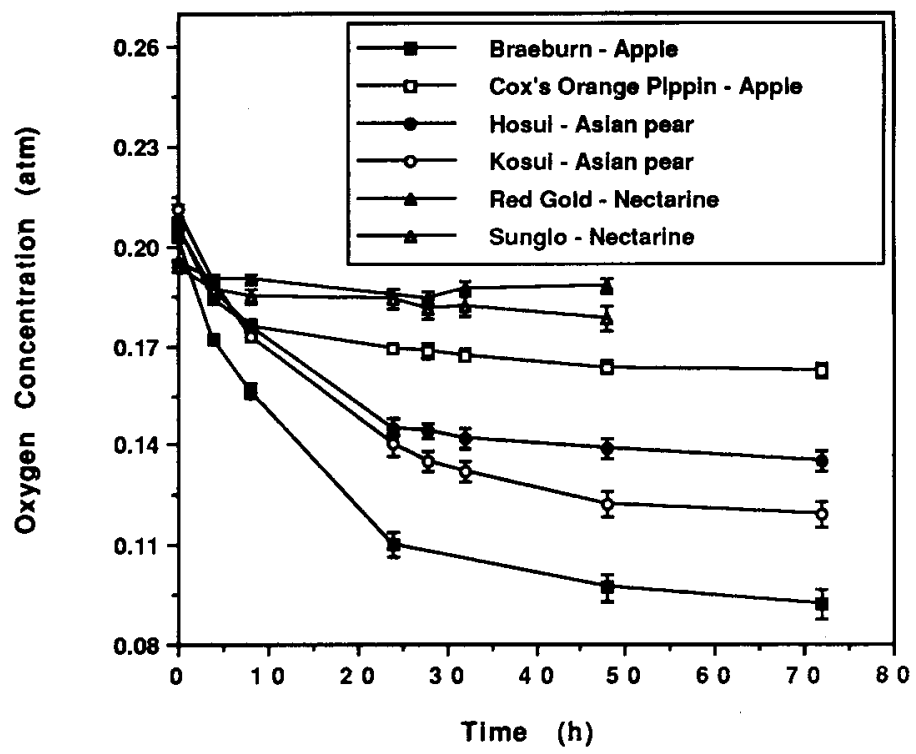

Fig. 2. Change in chamber $\mathrm{O}_{2}$ concentration with time. Vertical bars indicate the standard error. Each point represents mean of 10 fruits. 
$\mathrm{O}_{2}$ concentrations were not significantly different thereafter, indicating that samples taken from chambers after these times (i.e., $48 \mathrm{hr}$ in apples and Asian pears and $8 \mathrm{hr}$ in nectarines) could be used to estimate the internal atmosphere beneath the skin of these fruits.

Respiration rate of representative fruits of apples and Asian pears did not change significantly during the experimental period (96 hr) (Table 1) and, therefore, we assumed that the gas exchange of these fruits was at steady state. In nectarines, respiration rate did not change significantly during the first $48 \mathrm{hr}$ but declined thereafter. This decline in respiration rate would not have affected estimates of diffusivity because internal atmosphere measurements on the nectarines were completed within $48 \mathrm{hr}$ after removal from storage.

Oxygen concentrations beneath the skin and at the center of the fruit varied significantly among different crops (Table 2). Nectarines had higher $\left[\mathrm{O}_{2}\right]_{\mathrm{s}}$ and $\left[\mathrm{O}_{2}\right]_{\mathrm{c}}$ than apples and Asian

Table 1. Respiration rate of representative fruits maintained at 20C for 4 days.

\begin{tabular}{lllll}
\hline \hline & \multicolumn{4}{c}{ Respiration rate $^{\mathrm{z}} \mathrm{O}_{2} / \mathrm{cm}^{3}$ tissue/sec) $\times 10^{-6}$} \\
\cline { 2 - 5 } Cultivar & Day 1 & Day 2 & Day 3 & Day 4 \\
\hline Apple & & & & \\
$\quad$ Braeburn & $4.6 \mathrm{ab} \mathrm{A}^{y}$ & $4.1 \mathrm{ab} \mathrm{A}$ & $4.4 \mathrm{ab} \mathrm{A}$ & $4.3 \mathrm{ab} \mathrm{A}$ \\
$\quad$ Cox's Orange Pippin & $7.3 \mathrm{c} \mathrm{A}$ & $6.8 \mathrm{c} \mathrm{A}$ & $6.4 \mathrm{c} \mathrm{A}$ & $7.3 \mathrm{c} \mathrm{A}$ \\
Asian pears & & & & \\
$\quad$ Hosui & $3.5 . \mathrm{a} \mathrm{A}$ & $3.8 \mathrm{a} \mathrm{A}$ & $3.5 \mathrm{a} \mathrm{A}$ & $3.4 \mathrm{a} \mathrm{A}$ \\
$\quad$ Kosui & $5.3 \mathrm{~b} \mathrm{~A}$ & $5.5 \mathrm{~b} \mathrm{~A}$ & $4.6 \mathrm{~b} \mathrm{~A}$ & $4.9 \mathrm{~b} \mathrm{~A}$ \\
Nectarines & & & & \\
$\quad$ Red Gold & $20.3 \mathrm{~d} \mathrm{~A}$ & $19.4 \mathrm{~d} \mathrm{~A}$ & $16.7 \mathrm{~d} \mathrm{~B}$ &..$- \times$ \\
$\quad$ Sunglo & $19.5 \mathrm{~d} \mathrm{~A}$ & $22.3 \mathrm{~d} \mathrm{~A}$ & $16.0 \mathrm{~d} \mathrm{~B}$ & $14.9 \mathrm{~d} \mathrm{~B}$ \\
\hline
\end{tabular}

${ }^{z}$ Means of six replicate fruits.

yMean separation at $P=0.05$ within columns and rows by Duncan's multiple range test, lower and uppercase letters, respectively.

${ }^{x}$ Not measured. pears. There was no difference in [02], between either cultivars of Asian pears or nectarines, while it was lower in 'Braeburn' apples than in 'Cox's Orange Pippin'. $\left[\mathrm{O}_{2}\right]_{\mathrm{c}}$ followed a similar trend, but 'Hosui' pears had a lower $\left[\mathrm{O}_{2}\right]_{\mathrm{c}}$ than 'Kosui' pears.

Skin resistance to $\mathrm{O}_{2}$ diffusion was lowest in nectarines, while the highest $\mathrm{R}$ value was found in 'Braeburn' apples (Table 2); here, $\mathrm{R}$ was about four times higher than for 'Cox's Orange Pippin' apples. R of Asian pears was intermediate in value, but 'Hosui' fruit had a higher R than 'Kosui' fruits.

Respiration rates of nectarine were higher than those of apples and Asian pears (Table 2). 'Cox's Orange Pippin' apples were respiring about twice as rapidly as 'Braeburn' fruit.

The differences in $\left[\mathrm{O}_{2}\right]_{\mathrm{s}}$ of different crops were associated with variation in $\mathrm{R}$ and fruit respiration rate. High $\mathrm{R}$ reduces $\mathrm{O}_{2}$ movement across the skin and results in lower $\left[\mathrm{O}_{2}\right]_{\mathrm{s}}$ for a given respiration rate. $\mathrm{R}$ depends on skin characteristics such as thickness of the cuticle, number of open lenticels, surface cracks, and wax deposits. Skin characteristics are affected by genetic and environmental factors (Pratt, 1988). It would be interesting to determine exactly which characteristics contribute to the difference in $\mathrm{R}$ in various cultivars.

Only a slight $\mathrm{O}_{2}$ gradient developed between the surface and center of 'Cox's Orange Pippin' apples, whereas 'Braeburn' apples had a higher $\mathrm{O}_{2}$ gradient (Fig. 3). Nectarines and Asian pears also had high $\mathrm{O}_{2}$ gradients across the flesh, but no significant difference was found between the two nectarine cultivars. Although both Asian pear cultivars had a similar $\left[\mathrm{O}_{2}\right]_{s}$, $\mathrm{O}_{2}$ gradients within flesh tissues of 'Hosui' fruits were higher than those of 'Kosui' fruits.

Once $\mathrm{O}_{2}$ moves across the skin, it can diffuse within the flesh tissue in intercellular air channels and/or in the fluid/solid phase of the cellular matrix. The gas and fluid/solid phase of $\mathrm{O}_{2}$ diffusion in the cellular matrix of flesh tissues may be explained by a parallel model (diffusion either in air channels or in the fluid/solid phase) or by a series model (diffusion through air channels and fluid/solid phase in turn) using the analogy of the

Table 2. Equilibrated $\mathrm{O}_{2}$ concentration beneath the skin $\left(\left[\mathrm{O}_{2}\right]_{\mathrm{s}}\right)$ and at the center of the fruit $\left(\left[\mathrm{O}_{2}\right]_{\mathrm{c}}\right)$, skin resistance to $\mathrm{O}_{2}$ diffusion $(\mathrm{R})$, respiration rate $(\mathrm{a})$, intercellular space volume $\left.(\epsilon]\right)$ and flesh firmness $(\mathrm{F})$ of fruit cultivars maintained at 20C for $72 \mathrm{hr}$ (apple and Asian pear cultivars) or $36 \mathrm{hr}$ (nectarine cultivars).

\begin{tabular}{|c|c|c|c|c|c|c|}
\hline Cultivar & $\begin{array}{l}{\left[\mathrm{O}_{2}\right]_{\mathrm{s}}} \\
(\mathrm{atm}) \\
\end{array}$ & $\begin{array}{l}{\left[\mathrm{O}_{2}\right]_{\mathfrak{c}}} \\
(\mathrm{atm}) \\
\end{array}$ & $\begin{array}{c}\mathrm{R} \\
\left(\mathrm{sec} \cdot \mathrm{cm}^{-1}\right) \\
\end{array}$ & $\begin{array}{c}\mathrm{a} \times 10^{-6} \\
\left(\mathrm{ml} \mathrm{O}_{2} / \mathrm{cm}^{3} / \mathrm{sec}\right)\end{array}$ & $\begin{array}{c}\epsilon \\
(\%)\end{array}$ & $\begin{array}{c}F \\
(N)\end{array}$ \\
\hline \multicolumn{7}{|l|}{ Apple } \\
\hline Braeburn (BR) & 0.117 & 0.106 & 23,360 & 3.8 & 14.1 & 41.2 \\
\hline Cox's Orange Pippin (CX) & 0.151 & 0.148 & 5,939 & 7.8 & 17.4 & 39.2 \\
\hline \multicolumn{7}{|l|}{ Asian pears } \\
\hline Hosui (HS) & 0.137 & 0.106 & 13,603 & 4.6 & 1.7 & 24.5 \\
\hline Kosui (KS) & 0.138 & 0.125 & 11,031 & 6.0 & 2.5 & 25.5 \\
\hline \multicolumn{7}{|l|}{ Nectarine } \\
\hline Red Gold (RG) & 0.192 & 0.169 & 914 & 19.7 & 8.0 & 34.3 \\
\hline Sunglo (SG) & 0.190 & 0.166 & 950 & 20.3 & 4.0 & 5.9 \\
\hline \multicolumn{7}{|l|}{ Contrasts ${ }^{y}$} \\
\hline \multicolumn{7}{|l|}{ Crop } \\
\hline Apple vs. Asian pear & NS & $* *$ & $* * *$ & $* *$ & $* * *$ & $* *$ \\
\hline Apple vs. nectarine & $* * *$ & $* * *$ & $* * *$ & $* * *$ & $* * *$ & $* *$ \\
\hline Asian pear vs. nectarine & $* * *$ & $* * *$ & $* * *$ & $* * *$ & $* * *$ & $* *$ \\
\hline \multicolumn{7}{|l|}{ Cultivar (crop) } \\
\hline CX vs. BR & $* * *$ & $* * *$ & $* * *$ & $* * *$ & $* * *$ & NS \\
\hline HS vs. KS & NS & $* * *$ & $* * *$ & $*$ & $* * *$ & NS \\
\hline RG vs. SG & NS & NS & NS & NS & $* * *$ & $* *$ \\
\hline
\end{tabular}

${ }^{\mathrm{z}}$ Means of 15 replicate fruits.

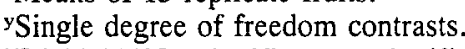

Ns,*,**,***Nonsignificant or significant at $P=0.05,0.01$, and 0.001 , respectively.

J. Amer. Soc. Hort. Sci. 115(5):793-797. 1990. 


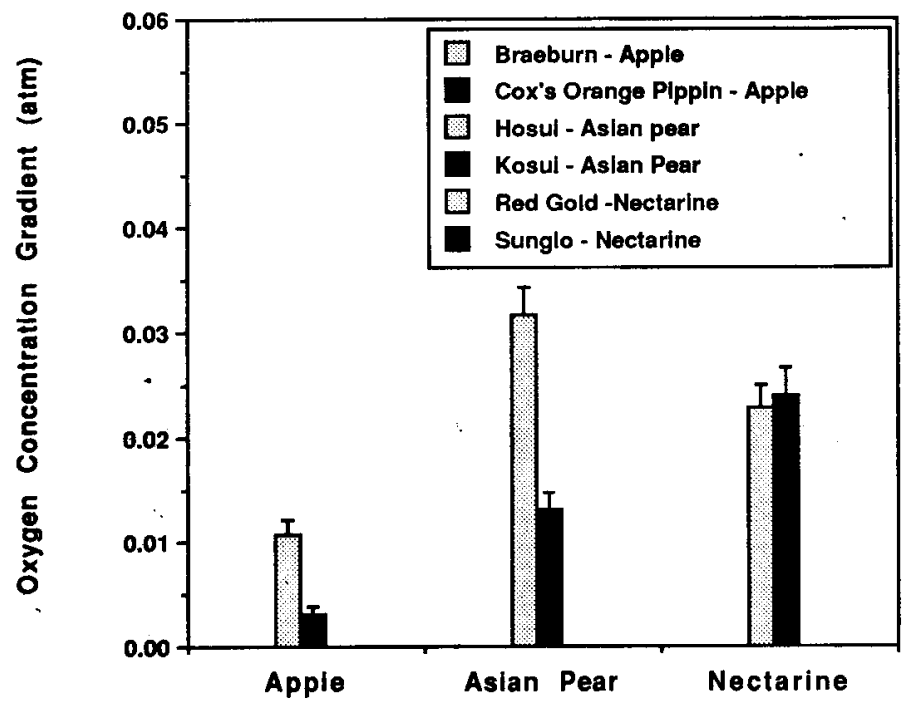

Fig. 3. Oxygen concentration gradient between tissues beneath the skin and center of the fruit maintained at 20C for $72 \mathrm{hr}$ (apple and Asian pear cultivars) or $36 \mathrm{hr}$ (nectarine cultivars). Vertical bars indicate the standard error. Each bar represents mean of 15 fruits.

Table 3. Comparison of estimated and calculated diffusivity $\left(\mathrm{D}_{\mathrm{e}}\right)$, using parallel and series models of diffusion, of $\mathrm{O}_{2}$ in flesh tissues of fruit cultivars. ${ }^{2}$

\begin{tabular}{|c|c|c|c|c|}
\hline \multirow[b]{2}{*}{ Cultivar } & \multirow{2}{*}{$\begin{array}{c}\text { Estimated } \\
\mathrm{D}_{\mathrm{e}} \times 10^{-3} \\
\left(\mathrm{~cm}^{2} \cdot \mathrm{sec}^{-1}\right)^{y}\end{array}$} & \multicolumn{3}{|c|}{$\begin{array}{l}\text { Calculated } D_{e} \times \\
10^{-3}\left(\mathrm{~cm}^{2} \cdot \mathrm{sec}^{-1}\right)\end{array}$} \\
\hline & & & $\begin{array}{l}\text { Series } \\
\text { model }\end{array}$ & $\begin{array}{c}\text { Parallel } \\
\text { model }\end{array}$ \\
\hline \multicolumn{5}{|l|}{ Apple } \\
\hline Braeburn & $1.2 \pm 0.3$ & 0.018 & $3 \pm 0.00006$ & $28.1 \pm 0.7$ \\
\hline Cox's Orange Pippin & $2.7 \pm 1.0$ & 0.017 & $7 \pm 0.00005$ & $34.9 \pm 0.5$ \\
\hline \multicolumn{5}{|l|}{ Asian pears } \\
\hline Hosui & $0.3 \pm 0.2$ & 0.021 & \pm 0.00002 & $3.4 \pm 0.3$ \\
\hline Kosui & $1.1 \pm 0.3$ & 0.020 & \pm 0.00002 & $5.0 \pm 0.3$ \\
\hline \multicolumn{5}{|l|}{ Nectarine } \\
\hline Red Gold & $1.7^{\circ} \pm 0.2$ & 0.019 & \pm 0.00006 & $16.0 \pm 0.6$ \\
\hline Sunglo & $1.8 \pm 0.2$ & 0.020 & \pm 0.00004 & $8.1 \pm 0.4$ \\
\hline
\end{tabular}

${ }^{2}$ Means of 15 replicate fruits.

y Number followed by mean indicates standard error.

combination of resistances in electrical circuits (Armstrong, 1979). $\mathrm{D}_{\mathrm{e}}$ was estimated using Eq. [2] and compared with theoretical estimates of the diffusivity obtained using these two models. We assumed that $\mathrm{O}_{2}$ diffusivities in the gas and the fluid/solid phases were the same as those in air $\left(D_{5}\right)$ and water $\left(D_{w}\right)$ at $20 \mathrm{C}$ $\left[\mathrm{D}_{\mathrm{n}}=0.201\right.$ and $\mathrm{D}_{\mathrm{w}}=2.1 \times 10{ }^{-{ }^{3}} \mathrm{c} \mathrm{m}^{2} \cdot \mathrm{s}^{-1}$ (Armstrong, 1979)] and that gas-filled intercellular spaces were evenly distributed. If the diffusion of $\mathrm{O}_{2}$ in the intercellular space and in the fluid/solid phase of the cellular matrix is modeled by parallel models of diffusion, $\mathrm{D}_{\mathrm{e}}$ would be given by:

$$
D_{c}=\epsilon \cdot D_{a}+(1-\epsilon) \cdot D_{w},
$$

where $\epsilon=$ percent intercellular space volume.

Alternatively, if diffusion in gas and in fluid/solid phases is modeled by a series model, then $\mathrm{D}_{\mathrm{e}}$ would be given by:

$$
D_{e}^{-1}=\epsilon \cdot D_{a}^{-1}+(1-\epsilon) \cdot D_{w}{ }^{-1} \text {. }
$$

All average cultivar $\mathrm{D}_{\mathrm{e}}$ values (Table 3 ) fell between the two values calculated for the parallel and series models. This result suggests that the actual mechanism for $\mathrm{O}_{2}$ diffusion in fruit flesh is a combination of these models in which there are several parallel gas and fluid/solid pathways through the intercellular system but a proportion of the gas pathways is blocked by the fluid/solid phase, forcing some diffusion in series.

Values for $\mathrm{D}_{\mathrm{e}}$ may have been slightly overestimated because of the deviation of fruit shape from true sphericity. Another possible source of error might be in the assumption of uniform respiration rate and distribution of gas-filled intercellular space throughout the flesh. The $\mathrm{O}_{2}$ gradients observed in this study suggest that respiration rates in the center of fruit might be slightly different from those at the surface. Although there were measurable $\mathrm{O}_{2}$ concentration differences between the surface and center of these fruits, the $\mathrm{O}_{2}$ concentrations at the fruit center were high enough for the effects on respiration rate to have been small. Soudain and Phan Phuc (1979) reported that the distribution of intercellular space in 'Golden Delicious' apple tissues is variable, with tissues in the fruit center being denser than tissues at the surface.

Estimates of gas-filled intercellular space in this study varied widely in the different crop species and, to a lesser extent, with cultivar (Table 2) and stage of ripeness, as estimated by firmness change (Table 4). Variation in gas-filled intercellular space observed between the two nectarine cultivars could be partly due to the different ripeness levels at the time of measurement (as indicated by firmness measurements). Mean intercellular space in 'Red Gold' nectarines decreased as fruit firmness declined with ripening, and this was accompanied by an increase in $0_{2}$ gradients between surface and central tissues (Table 4). BenYehoshua et al. (1963) reported that resistance of avocado flesh tissues to gas diffusion increased with ripening. Cell walls and membranes break down and cell contents fill some intercellular spaces, increasing the resistance to $0_{2}$ movement, as plant organs become senescent (Kader et al., 1989). Large intercellular space volumes are generally assumed to provide an efficient means of aerating fruit tissues. The degree to which intercellular spaces are filled with cell sap associated with overripeness could greatly affect the diffusivity of $\mathrm{O}_{2}$ within the tissue (Burton, 1982).

A tissue with large intercellular space volume could develop large $\mathrm{O}_{2}$ gradients between the tissues beneath the fruit surface and the fruit center if the gas channels are blocked with cell sap and tissue $\mathrm{O}_{2}$ demand is high. Conversely, a tissue with a small intercellular space could have ample $\mathrm{O}_{2}$ supply if the intercellular space channels are free of blockage and respiration rate is low. Comparison of data in Tables 2 and 3 suggests that the estimated $\mathrm{D}_{e}$, and hence observed $\mathrm{O}_{2}$ gradients in this study, were broadly consistent with the estimated gas-filled intercellular space volumes and respiration rates of the different cultivars. Leonard (1939) showed that the volubility of $\mathrm{O}_{2}$ decreases

Table 4. Change in flesh firmness, intercellular space volume $(\epsilon]), \mathrm{O}$ concentrations beneath the skin $\left(\left[\mathrm{O}_{2}\right]_{\mathrm{s}}\right)$ and at the center $\left(\left[\mathrm{O}_{2}\right]_{\mathrm{c}}\right)$ and $\mathrm{O}_{2}$ gradient across flesh $\left(\Delta \mathrm{O}_{2}\right)$ of unripe and ripe 'Red Gold' nectarines. $^{\text {z.y }}$

\begin{tabular}{lccccc}
\hline \hline $\begin{array}{l}\text { Ripeness } \\
\text { stage }^{x}\end{array}$ & $\begin{array}{c}\text { Firmness } \\
(\mathrm{N})\end{array}$ & $\begin{array}{c}\epsilon \\
(\%)\end{array}$ & $\begin{array}{c}{\left[\mathrm{O}_{2}\right]_{\mathrm{s}}} \\
(\mathrm{atm})\end{array}$ & $\begin{array}{l}{\left[\mathrm{O}_{2}\right]_{\mathrm{c}}} \\
(\mathrm{atm})\end{array}$ & $\begin{array}{c}\Delta \mathrm{O}_{2} \\
(\mathrm{~atm})\end{array}$ \\
\hline Unripe & $34.3 \mathrm{a}$ & $8.0 \mathrm{a}$ & $0.192 \mathrm{a}$ & $0.169 \mathrm{a}$ & $0.023 \mathrm{a}$ \\
Ripe & $15.7 \mathrm{~b}$ & $3.7 \mathrm{~b}$ & $0.184 \mathrm{a}$ & $0.145 \mathrm{~b}$ & $0.039 \mathrm{~b}$ \\
SE & 1.3 & 0.6 & 0.009 & 0.008 & 0.009 \\
\hline
\end{tabular}

${ }^{2}$ Means of 15 replicate fruits.

${ }^{y}$ Means followed by the same letter are not significantly different at $P$ $=0.05$.

${ }^{x}$ Ripeness stage was assessed by change in firmness. 
with increasing sugar concentration in solution. This phenomenon could further reduce diffusivity of $\mathrm{O}_{2}$ in ripening and overripe fruits.

Table 5 shows the partitioning of the total $\mathrm{O}_{2}$ gradient between the external environment (assumed to be $0.2095 \mathrm{~atm}$ ) and fruit center. This would depend upon the relative resistances to gas diffusion offered by both skin and flesh. In apples and Asian pears, the majority of the total gradient was across the skin $(70 \%$ to $95 \%$ ). In nectarines, however, $\mathrm{O}_{2}$ gradients across the flesh were significant and slightly higher than those across the skin.

In this study, except perhaps for 'Cox's Orange Pippin' apples, fruit flesh has been shown to exert some resistance to $0_{2}$ diffusion, resulting in measurable $\mathrm{O}_{2}$ gradients between tissues immediately beneath the skin and those at the center of the fruit. The magnitude of these $\mathrm{O}_{2}$ concentration gradients varied between cultivars and, in 'Red Gold' nectarines, with stage of ripeness.

For any given external $\mathrm{O}_{2}$ level in CA/MA storage, the center of a fruit will normally experience significantly lower $\mathrm{O}_{2}$ levels than those at the surface if $\mathrm{D}_{\mathrm{e}}$ is low. The rate of $\mathrm{O}_{2}$-dependent processes could be different at the center and surface of a fruit. Under low- $\mathrm{O}_{2}$ environments, like those encountered in CA/MA storage, this could lead to some detrimental effects on internal quality of produce, such as development of disorders, off-flavors, and off-odors. At high storage temperatures, the minimum external $\mathrm{O}_{2}$ level for development of disorders would probably be higher because of elevated respiration rates. These findings will have implications for CA/MA storage of cultivars with relatively low $\mathrm{D}_{e}$, particularly at ambient or elevated temperatures. It maybe necessary to continuously change the external atmospheric composition in long-term CA/MA storage to compensate for any changes in respiration rate and skin and flesh resistance

Table 5. Proportion of total $\mathrm{O}_{2}$ gradient between external atmosphere assumed to be $0.2095 \mathrm{~atm}$ ) and internal core cavity across the skin and flesh.

\begin{tabular}{llc} 
& \multicolumn{3}{c}{$\begin{array}{c}\text { Percentage of total } \\
\mathrm{O}_{2} \text { gradient }^{\mathbf{z}}\end{array}$} \\
\cline { 2 - 3 } Cultivar & Skin & Flesh \\
\hline Apple & 89 & 11 \\
$\quad$ Braeburn & 95 & 4.5 \\
$\quad$ Cox's Orange Pippin & & 30 \\
Asian pears & 70 & 15 \\
$\quad$ Hosui & 85 & 56 \\
$\quad$ Kosui & & 55 \\
Nectarine & 44 & \\
$\quad$ Red Gold & 46 & \\
$\quad$ Sunglo & & \\
\hline
\end{tabular}

${ }^{2}$ Percentage gradients across the skin and flesh were calculated using mean $\left[\mathrm{O}_{2}\right]_{\mathrm{s}}$ and $\left[\mathrm{O}_{2}\right]_{\mathrm{c}}$ values from Table 2 . during storage (Wollin et al., 1985). Further investigations on $\mathrm{O}_{2}$ diffusion within flesh tissues will usefully enhance our knowledge of CA/MA effects on quality and will help in the optimization of CA/MA storage techniques for horticultural crops,

\section{Literature Cited}

Armstrong, W. 1979. Aeration in higher plants. Adv. Bot. Res. 7:226332.

Banks, N.H. 1986. Apparatus for determining oxygen in small samples. Ann. Applied Biol. 108:445-448.

Banks, N.H. and S.J. Kays. 1988. Measuring internal gases and len ticel resistance to gas diffusion in potato tubers. J. Amer. Soc. Hort. Sci. 113:577-580.

Ben-Yehoshua, S., R.N. Robertson, and J.B. Biale. 1963. Respiration and internal atmosphere of avocado fruit. Plant Physiol. 38: 194201.

Burg, S.P. and E.A. Burg. 1965. Gas exchange in fruit. Physiol. Plant. 18:870-884.

Burton, W.G. 1982. Postharvest physiology of food crops. Longman, London.

Carslaw, H.S. and J.C. Jaeger. 1959. Conduction of heat in solids. 2nd ed. Clarendon Press, Oxford, U.K.

Kader, A. A., D. Zagory, and E.L. Kerbel. 1989. Modified atmosphere packaging of fruits and vegetables. CRC Crit. Rev. Food Nutr. 28:130 .

Kushman, L.D. and D.T. Pope. 1968. Procedure for determining intercellular space of roots and specific gravity of sweet potato root tissue. HortScience 3:44-45.

Leonard, E.R. 1939. Studies in tropical fruits. VI. A preliminary consideration of volubility of gases in relation to respiration. Ann. Bet. New Ser. 3(12):825-843.

Nobel, P.S. 1983. Biophysical plant physiology and ecology. Freeman, San Francisco.

Pratt, C. 1988. Apple flower and fruit: morphology and anatomy. Hort. Rev. 10:273-308.

Rajapakse, N. C., N.H. Banks, E.W. Hewett, D.J. Cleland, and P.C. Austin. 1989. Oxygen concentration differences in apple fruit flesh. Proc. 4th Australasian Conf. on Heat and Mass Transfer 1989. Christchurch, New Zealand. p. 368-374.

Solomos, T. 1987. Principles of gas exchange. HortScience 22:766771.

Soudain, P. and A. Phan Phuc. 1979. La diffusion des gaz clans les tissus végétaux en rapport avec la structure des organes massifs. Perspectives nouvelles clans la conservation des fruits et légumes frais. Seminaire International, Centre de Recherches en Sciences Appliques a l'Alimentation, Université du Québec, Montréal, 14 15 Apr. 1978. p. 67-86.

Trout, S. A., E.G. Hall, R.N. Robertson, E.M.V. Hackney, and S.K. Sykes. 1942. Studies in the metabolism of apples. Austral. J. Expt. Biol. Med. Sci. 20:219-231.

Wollin, A. S., C.R. Little, and J.S. Packer. 1985. Dynamic control of storage atmospheres, p. 308-315. In: S.M. Blankenship (cd.). Controlled atmospheres for storage and transport of perishable agricultural commodities. Proc. 4th Natl. CA Res. Conf. North Carolina State Univ., Raleigh. Hort. Rpt. 126. 